\title{
Total and Merchantable Volume of White Spruce in Alaska
}

\author{
Thomas Malone, Jingiing Liang, and Edmond C. Packee Sr.
}

White spruce (Picea glauca [Moench] Voss) is a valuable commercial species found in interior and southcentral Alaska. Numerous regional and local volume tables or equations exist; however, no statewide model exists or has been tested for accuracy. There is a demand for an accurate model to determine the cubic-foot volume of white spruce trees in Alaska. Multiple models were developed for white spruce to estimate total and merchantable cubic-foot volume to a 2-, 4-, and 6-in. top. These multiple-entry (diameter and height) models were developed for both inside and outside bark volume from a 6 -in. stump. The models were tested on a regional basis at various geographic locations and were shown to be highly accurate. The Alaska models chosen have $R^{2}$ at or near 0.99 and mean square error from 0 to 0.16 for all models. These models are shown to be superior to other white spruce models in Alaska.

Keywords: volume model, white spruce, Alaska, boreal forest

I ndividual tree volume models are an essential tool for forest management activities (Avery and Burkhart 2002). They are used to estimate individual tree and total stand volume and to investigate biomass, carbon sequestration, and forest growth and yield (Brackley et al. 2010, Liang 2010, Woodall 2010). Resource managers have been estimating the volume of wood in trees for as long as there has been a forest products industry. The most common units for measuring tree volume are board feet, cubic feet, and cubic meters. Volume estimates were originally presented in volume tables. With the advent of computers, empirical volume equations became more widely used than volume tables. Equations are more convenient and flexible because they can be loaded into spreadsheets and data loggers. The current terminology for volume estimation tools is volume model, although the terms volume table and equations are still in use.

Oettelt (1765) estimated tree volume by comparing it with a cylinder of equal height and basal diameter; Smalian (1837) improved the model by comparing tree sections with the frustums of conoids (Bruce and Max 1989). Today, volume models have been developed for individual tree species or for multiple species in composite models (Avery and Burkhart 2002). Volume models are developed from a variety of explanatory variables such as $\mathrm{dbh}$, height, tree form, and age, with the first two being the most common variables (Schreuder et al. 1993, Huang et al. 2000, Avery and Burkhart 2002).

White spruce (Picea glauca [Moench] Voss) is a transcontinental species and the most widely distributed conifer in North America. It has high commercial value (Harlow et al. 1996) and ecological importance (Nienstaedt and Zasada 1990). White spruce is used commercially as structural lumber, house logs, plywood, musical string instruments, and pulpwood (Nienstaedt and Zasada 1990). It is also a valuable source of firewood and biomass. In Alaska, white spruce accounts for $64-81 \%$ of the commercial forest volume of the boreal forest (Hutchison 1967). White spruce is widely distributed in the state from the Canadian border in the east to the Bering Sea in the west and from north of the Brooks Range in the northeast to the Kenai Peninsula and the Bristol Bay area in the southwest (Figure 1). White spruce grows on a variety of soil parent materials including glacial, lacustrine, marine, alluvial (Nienstaedt and Zasada 1990), aeolian, residual, and colluvial (Soil Staff Survey 1999). In Alaska, the largest white spruce are approximately $130 \mathrm{ft}$ tall and can reach 34 in. at dbh. White spruce is a thin bark species (Viereck and Little 2007) that tapers quickly from the stump to the main stem.

With the rising global and local demand for timber and woodbased energy (State of Alaska 2007), a model to estimate both merchantable and total stem volume of white spruce for forest resources in Alaska is of great need and importance (Liang 2010, 2012, Liang et al. 2011). Existing white spruce volume models in Alaska are of limited applicability because of small sample size or limited sample geographic coverage. The published cubic-foot volume models of Gregory and Haack (1964) were developed with 434 sample trees mostly from interior Alaska, and that of Larson and Winterberger (1988) was developed from 244 white spruce and 43 black spruce trees harvested from the Matanuska and Susitna Valleys. In addition, numerous unpublished volume models based on data sets from small and scattered geographic areas exist.

The objective of this study was to develop a single model to estimate cubic-foot volume of white spruce in Alaska in each of eight categories (total stem volume both outside and inside bark and merchantable volume outside and inside bark to a 2-, 4-, and 6-in. top).

Manuscript received February 2, 2012; accepted December 20, 2012. http://dx.doi.org/10.5849/wjaf.12-003.

Thomas Malone (tmalone@alaska.edu), University of Alaska Fairbanks, Department of Forest Sciences, Fairbanks, AK. Jingjing Liang (jilang@mail.wvu.edu), West Virginia University. Edmond C. Packee Sr. (ecpackee@alaska.edu), University of Alaska Fairbanks, Emeritus. This research was supported in part by the US Department of Agriculture, McIntire-Stennis Act Fund ALK-03-12, and by the School of Natural Resources and Agricultural Sciences, University of Alaska Fairbanks. We thank the many land management agencies, both private and government, that allowed us to collect this data on their lands and the numerous technicians and students who assisted in data collection.

Copyright (C) 2013 by the Society of American Foresters. 


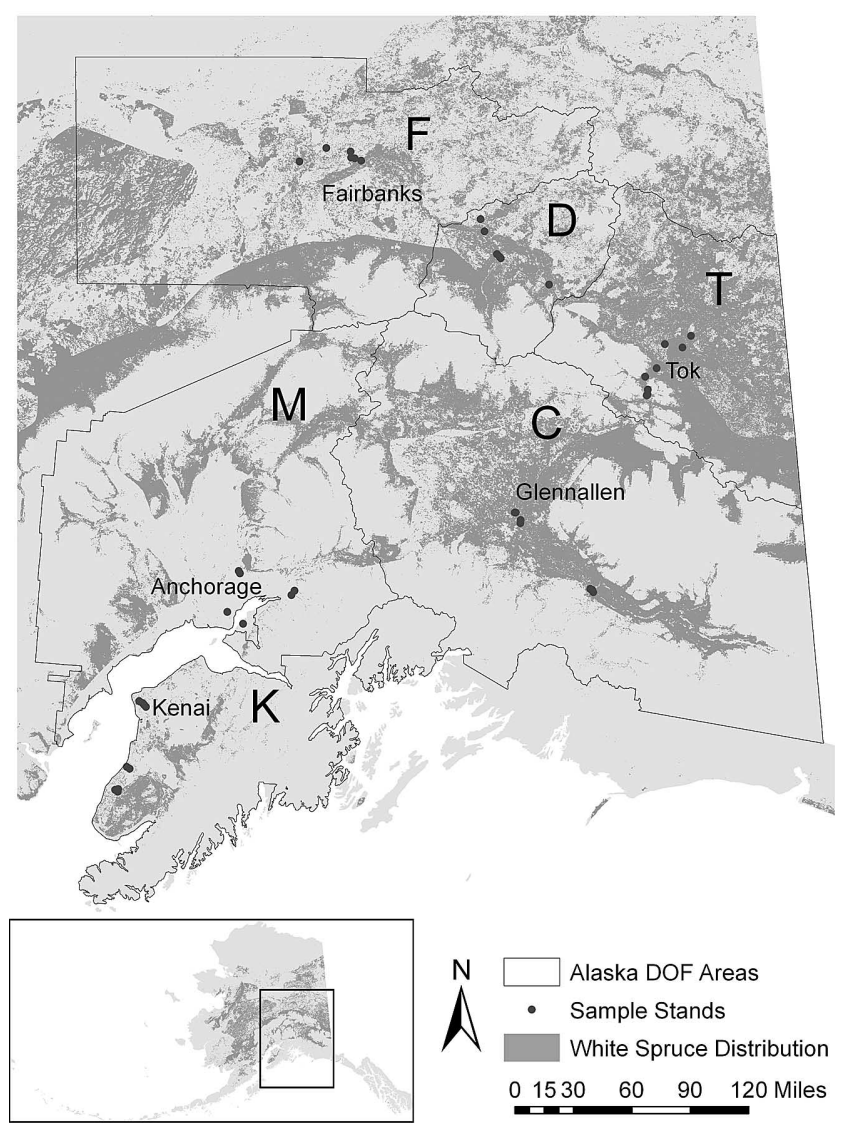

Figure 1. Geographic distribution of the $\mathbf{4 3}$ white spruce volume sample sites. Alaska Division of Forestry (DOF) areas: C, Copper River Valley; D, Delta area; F, Fairbanks area; K, Kenai Peninsula; M, Matanuska-Susitna Valleys; T, Tok area (Maisch 2009, Ruefenacht et al. 2008).

\section{Data and Methods \\ Data Collection}

A total of 2,016 white spruce trees were sampled from 43 commercial forest stands located throughout six Alaska Department of Forestry (DOF) designated areas (Maisch 2009) of interior and southcentral Alaska: Copper River Valley, Delta, Fairbanks, Kenai Peninsula, Matanuska-Susitna (Mat-Su) Valleys, and Tok (Figure 1). Within each DOF area, sampling locations were randomly selected from stands where trees were being commercially harvested or were available to cut. Sample trees were randomly selected in each stand with four criteria: (1) sample trees must be felled and situated in a safe location for measurement; (2) sample trees were free of major defects from the base to the tip; (3) sample trees must have a dbh no less than 2 in.; and (4) no more than 150 trees would be sampled per stand. Sample trees were representative of dominant, codominant, intermediate, and understory crown classes (Table 1). There was no effort to ensure that there was an even distribution of sample trees by size.

All sample trees were felled and delimbed along the top and on one side of the stem to facilitate accurate height and dbh measurements. Data collected for each sample tree were the following: crown class, total height, length of live crown, and diameter outside bark (regardless of abnormalities) every $4 \mathrm{ft}$ along the main stem from a 6-in. high stump to the tip. Length was measured with a tape measure to the nearest $0.1 \mathrm{ft}$, and diameter was measured with a diameter tape outside bark to the nearest 0.1 in.
Table 1. Distribution and number of sample trees by total height and $\mathrm{dbh}$ for both the Alaska model data set and the validation (postsample) data set.

\begin{tabular}{|c|c|c|c|c|c|c|c|c|c|c|}
\hline \multirow[b]{2}{*}{ dbh (in.) } & \multicolumn{10}{|c|}{ Total height (ft) } \\
\hline & 20 & 30 & 40 & 50 & 60 & 70 & 80 & 90 & $100+$ & Total \\
\hline & \multicolumn{10}{|c|}{ Calibration data set } \\
\hline 2 & 1 & 2 & & & & & & & & 3 \\
\hline 4 & 14 & 47 & 20 & 2 & & & & & & 83 \\
\hline 6 & 1 & 30 & 98 & 60 & 12 & 1 & & & & 202 \\
\hline 8 & & 1 & 39 & 135 & 127 & 47 & 5 & & & 354 \\
\hline 10 & & & 5 & 53 & 202 & 148 & 47 & 10 & & 465 \\
\hline 12 & & & & 11 & 87 & 127 & 70 & 30 & 3 & 328 \\
\hline 14 & & & & 1 & 21 & 69 & 53 & 39 & 19 & 202 \\
\hline 16 & & & & & 4 & 16 & 18 & 24 & 16 & 78 \\
\hline 18 & & & & & 1 & 8 & 17 & 5 & 17 & 48 \\
\hline 20 & & & & & & 1 & 3 & 10 & 22 & 36 \\
\hline $22+$ & & & & & & & & 1 & 15 & 16 \\
\hline \multirow[t]{2}{*}{ Total } & \multirow{2}{*}{\multicolumn{10}{|c|}{ Validation data set }} \\
\hline & & & & & & & & & & \\
\hline 2 & & & & & & & & & & \\
\hline 4 & 3 & 5 & & 1 & & & & & & 9 \\
\hline 6 & & 3 & 12 & 10 & 3 & & & & & 28 \\
\hline 8 & & & & 14 & 13 & 6 & 2 & & & 35 \\
\hline 10 & & & & 5 & 28 & 13 & 6 & & & 52 \\
\hline 12 & & & & 2 & 4 & 13 & 8 & 3 & & 30 \\
\hline 14 & & & & & 3 & 5 & 6 & 2 & 3 & 19 \\
\hline 16 & & & & & & 1 & 5 & 4 & 3 & 13 \\
\hline 18 & & & & & & 1 & & 2 & 3 & 6 \\
\hline 20 & & & & & & 1 & 2 & & 1 & 4 \\
\hline $22+$ & & & & & & & & & 5 & 5 \\
\hline Total & & & & & & & & & & 201 \\
\hline
\end{tabular}

Table 2. Sample tree distribution by DOF area.

\begin{tabular}{lccr}
\hline \multicolumn{1}{c}{ DOF area } & Calibration data set & Validation data set & Total \\
\hline Copper River Valley & 328 & 36 & 364 \\
Delta area & 323 & 36 & 359 \\
Fairbanks area & 307 & 34 & 341 \\
Kenai Peninsula & 353 & 39 & 392 \\
Mat-Su Valley & 205 & 23 & 228 \\
Tok area & 299 & 33 & 332 \\
Total & 1,815 & 201 & 2,016 \\
\hline
\end{tabular}

Approximately $10 \%$ of the sample trees from each DOF area (Table 2) were randomly selected and reserved to validate model accuracy. A total of 201 validation trees were selected, and the remaining 1,815 trees were used to develop the models.

Stem volume outside bark of each sample tree was calculated as the sum of the volume of each $4-\mathrm{ft}$ section, which was estimated using the Smalian formula (Husch et al. 1993). Stem volume inside bark was estimated by subtracting double-bark thickness from $\mathrm{dbh}$ outside bark. Bark thickness was estimated using the white spruce bark thickness model of Malone and Liang (2009), developed from the same geographic areas as these volume data. In estimating the merchantable volume, the top section of each sample tree was set as the first section containing a merchantable top diameter, i.e., 2, 4, or 6 in.

\section{Model Estimation and Validation}

The models to estimate total stem volume outside $\left(V_{1}\right)$ and inside $\left(V_{2}\right)$ bark were selected from a series of candidate models based on the goodness of fit, level of significance of all coefficients, and residual patterns. The candidate models consisted of various forms of dbh $(D)$ and height $(H)$ including $D, D^{2}, \ln (D),(D H),\left(D^{2} H\right)$, $\left(D^{2} H^{2}\right), H, H^{2},\left(D^{-2} H^{-1}\right)$, and $\ln (H)$. Two different forms of 
Table 3. Alaska models to estimate total and merchantable volume of white spruce in Alaska.

\begin{tabular}{|c|c|c|c|c|}
\hline Model & Estimated parameters & $R^{2}$ & $\mathrm{CF}$ & MSE \\
\hline \multicolumn{5}{|l|}{ Total stem volume } \\
\hline Outside bark & $\left.\ln V_{1}=-5.7308^{* * *}+(1.7837 \ln D)^{* * *}+1.0613 \ln H\right)^{* * *}$ & 0.994 & 1.005 & 0.005 \\
\hline Inside bark & $\left.\ln V_{2}=-6.1352^{* * *}+(1.8517 \ln D)^{* * *}+1.0691 \ln H\right)^{* * *}$ & 0.994 & 1.005 & 0.005 \\
\hline \multicolumn{5}{|l|}{ Merchantable volume } \\
\hline Outside bark to a 2 -in. top & $M_{1,2}=-0.0734^{* * *}+0.9999 V_{1}^{* * *}+0.00003 D+0.0001 H$ & 0.999 & & 0.001 \\
\hline Inside bark to a 2 -in. top & $M_{2,2}^{1,2}=-0.0720^{* * *}+0.9999 V_{2}^{* * *}+0.0001 D+0.0001 H$ & 0.999 & & 0.000 \\
\hline Outside bark to a 4 -in. top & $M_{1,4}=-0.7100^{* * *}+0.9982 V_{1}^{* * *}+0.0354 D^{* * *}-0.0028 H^{* * *}$ & 0.999 & & 0.016 \\
\hline Inside bark to a 4 -in. top & $M_{2,4}^{1,4}=-0.8940^{* * *}+0.9963 V_{2}^{* * *}+0.0488 D^{* * *}-0.0032 H^{* * *}$ & 0.999 & & 0.019 \\
\hline Outside bark to a 6 -in. top & $M_{1,6}=-3.1100^{* * *}+0.9891 V_{1}^{* * *}+0.2036 D^{* * *}-0.0146 H^{* * *}$ & 0.999 & & 0.143 \\
\hline Inside bark to a 6 -in. top & $M_{2,6}^{1,0}=-3.5510^{* * *}+0.9840 V_{2}^{* * *}+0.2541 D^{* * *}-0.0198 H^{* * *}$ & 0.999 & & 0.158 \\
\hline \multicolumn{5}{|c|}{ Merchantable volume (two-stage model) } \\
\hline Outside bark to a 2 -in. top & $M_{1,2}=-0.441+0.982 \hat{V}_{1}^{* * *}+0.0128 D+0.00876 H$ & 0.989 & & 4.507 \\
\hline Inside bark to a 2 -in. top & $M_{2,2}=-0.987^{* * *}+0.948 \hat{V}_{2}^{* * *}+0.0825 D^{* *}+0.0138 H^{* *}$ & 0.989 & & 3.602 \\
\hline Outside bark to a 4-in. top & $M_{1,4}=-1.12^{* * *}+0.979 \hat{V}_{1}^{* * *}+0.0530 \mathrm{D}+0.0061 \mathrm{H}$ & 0.989 & & 5.193 \\
\hline Inside bark to a 4 -in. top & $M_{2,4}^{1,4}=-1.96^{* * *}+0.941 \hat{V}_{2}^{* * *}+0.144 D^{* * *}+0.0116 H^{*}$ & 0.988 & & 3.781 \\
\hline Outside bark to a 6 -in. top & $M_{1,6}=-3.86^{* * *}+0.964 \hat{V}_{1}^{* * *}+0.2497 D^{* * *}-0.00305 H$ & 0.987 & & 5.978 \\
\hline Inside bark to a 6 -in. top & $M_{2,6}=-5.14^{* * *}+0.920 \hat{V}_{2}^{* * *}+0.386 D^{* * *}-0.00095 H$ & 0.986 & & 4.498 \\
\hline
\end{tabular}

dependent variables, $V$ and $\ln (V)$ were also tested. Although all models tested had high goodness of fit (adjusted $R^{2}>90 \%$ ) and high levels of significance $(P<0.05)$, most models were rejected based on analysis of residuals.

The selected total stem volume model is

$$
\begin{aligned}
& \ln V_{1}=\alpha_{0}+\alpha_{1} \cdot \ln D+\alpha_{2} \cdot \ln H \\
& \ln V_{2}=\beta_{0}+\beta_{1} \cdot \ln D-\beta_{2} \cdot \ln H
\end{aligned}
$$

where $\alpha$ and $\beta$ are parameters estimated with the ordinary least squares method (Ryan et al. 2005). To correct the bias introduced by a $\log$ transformation (Sprugel 1983), predicted volumes $V_{1}$ and $V_{2}$ should be multiplied by a correction factor (Baskerville 1972).

Merchantable volume $\left(M_{i, j}\right)$ was determined by observed total stem volume $\left(V_{1}\right.$ or $\left.V_{2}\right), \mathrm{dbh}(D)$, and height $(H)$ with a linear model:

$$
M_{i, j}=\gamma_{0}+\gamma_{1} \cdot V_{i}+\gamma_{2} \cdot D+\gamma_{3} H
$$

where $M_{i, j}$ represents merchantable volume outside $(i=1)$ and inside $(i=2)$ bark, to a $j$-in. top, and $\gamma$ are parameters to be estimated with ordinary least squares. The observed total volumes, $V_{1}$ and $V_{2}$, were used as independent variables for this model.

Because in practice it is often difficult to obtain observed total volume data, we further developed a two-stage merchantable volume model to predicted merchantable volume based on the predicted total stem volume (Wooldrige 2009):

$$
M_{i, j}=\delta_{0}+\delta_{1} V_{i}+\delta_{2} D+\delta_{3} H
$$

where $\hat{V}_{1}$ and $\hat{V}_{2}$ are total stem volumes predicted by model 1 and $\delta$ are coefficients.

Total and merchantable volume models were examined with the coefficient of determination $\left(R^{2}\right)$ and residual patterns and were further tested for accuracy and geographic variation. The accuracy of the models chosen was determined by the postsample prediction errors, the difference between the predicted and actual observed total and merchantable volume of the 201 validation sample trees. Predictions of the merchantable volume model to a 4 -in. top were compared against observed values and predictions of three other white spruce volume models used in Alaska (Haack 1963, Beagle 1979, Larson and Winterberger 1988). The 201 validation samples were used to test the hypothesis that a statewide volume model could be accurate for applications across the region and within the six DOF areas. The total stem volume outside-bark model is presented as an example of the accuracy of the Alaska statewide models.

\section{Results}

The model of total stem volume outside bark developed for white spruce in Alaska was

$$
\ln V_{1}=-5.7308+(1.7837 \ln D)+(1.0613 \ln H)
$$

For users who are not familiar with logarithmic transformations, the above model is also presented in exponential form when the correction factor for log transformation has been taken into account:

$$
V_{1}=0.00326 D^{1.7837} H^{1.0613}
$$

The model of total stem volume inside bark was also developed with the same form (Table 3). The model to estimate merchantable volume outside bark to a 2-in. top was

$M_{1,2}=-0.0734+0.9999 V_{1}-0.00003 D+0.000094 H$

The models of merchantable volume inside and outside bark to a 4- and 6-in. top were also developed in the same form (Table 3). All selected total and merchantable models (Table 3) show high coefficients of determination $\left(R^{2}>99 \%\right)$ and high levels of significance $(P<0.0005)$. Residuals of the total stem volume inside and outside bark were normally distributed without any discernible pattern of bias (Figure 2A and B). Residual patterns of the merchantable volume models appear to be more complex (Figure $2 \mathrm{C}-\mathrm{H}$ ), but as the merchantable top diameter increases from 2 to 6 in., the residuals became centered around 0 with a less discernible pattern. There were a few suspicious outlying residuals (Figure $2 \mathrm{~A}$ and $\mathrm{B}$ ), but the Cook's distance test $(P \geq 0.05)$ indicated that none of them was an influential outlier (Neter et al. 1996, Ryan et al. 2005). This result is expected with such a large sample size. 

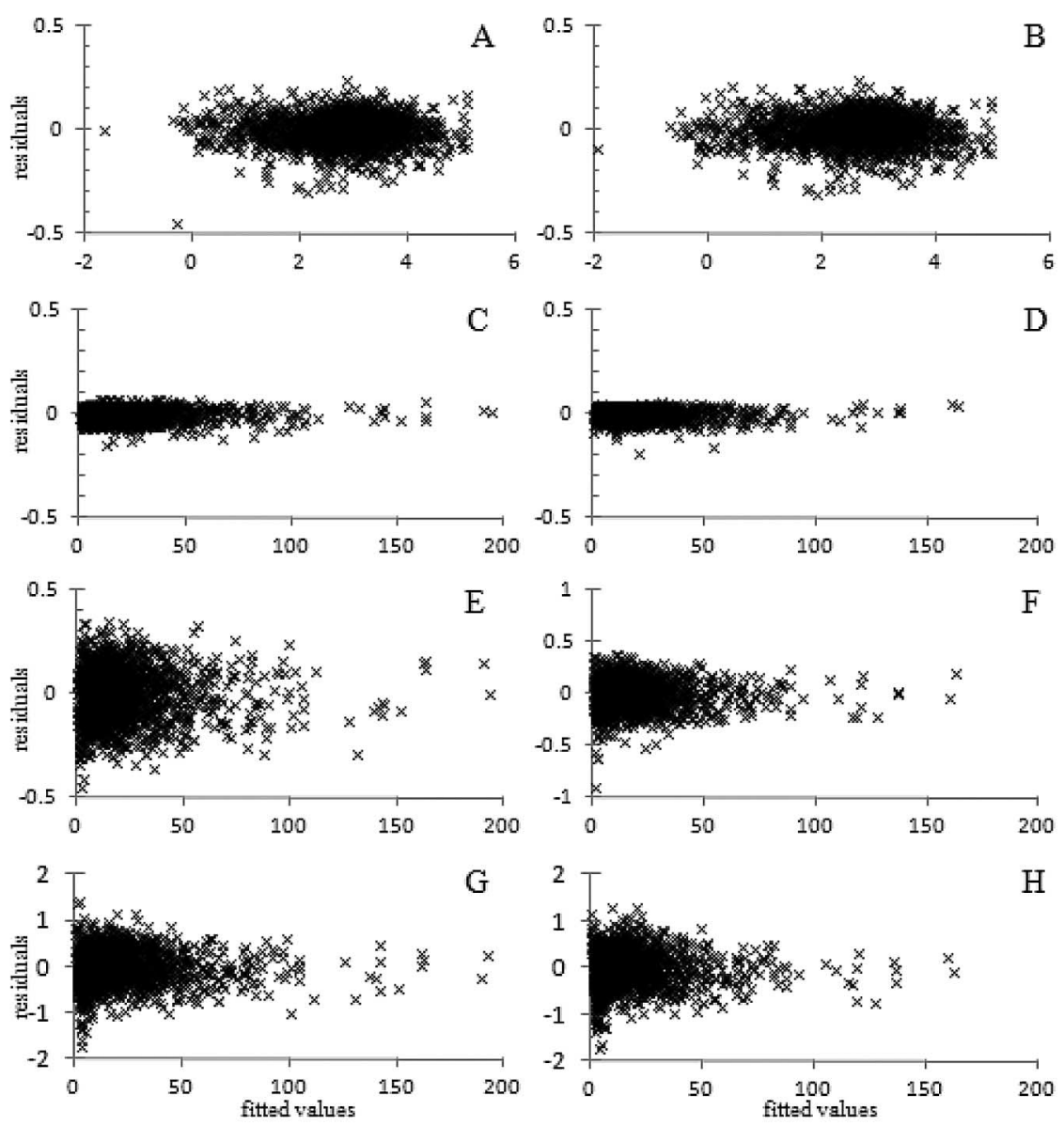

Figure 2. Residual versus fitted values of the total and merchantable volume models of white spruce in Alaska. A. Total stem volume outside bark. B. Total stem volume inside bark. C. Merchantable volume to a 2 -in. top outside bark. D. Merchantable volume to a 2 -in. top inside bark. E. Merchantable volume to a 4-in. top outside bark. F. Merchantable volume to a 4-in. top inside bark. G. Merchantable volume to a 6-in. top outside bark. H. Merchantable volume to a 6-in. top inside bark.

The accuracy of the merchantable volume model to a 4-in. top inside bark was analyzed by comparing the predicted stem volumes against the observed values of the 201 validation samples. Figure 3 was developed to test the accuracy of the four white spruce volume models with an independent set of postsample data. Three of the models, Haack (1963), Beagle (1979), and Larson and Winterberger (1988), were published previously and the fourth is the Alaska statewide model (this article). The Alaska statewide merchantable volume model was obviously more accurate than the three other volume models that overestimated the merchantable volume of trees of all sizes. For all validation samples, the average predicted Alaska merchantable volumes were all within the $95 \%$ confidence interval of the observed mean (Figure 3). The average difference between the mean predicted and the observed stem volumes is $-0.06 \mathrm{ft}^{3}$, which accounts for $<0.1 \%$ of the observed mean.

Compared with the six DOF individual area models, the Alaska statewide total volume model exhibited no practical or statistical difference in the predictions of the 201 validation samples. Total estimated volumes by dbh using the statewide model and the six individual area models were all similar and fell within the 95\% confidence interval of the observed means (Figure 4).

In addition, the Alaska model was tested with the validation samples by DOF area. All the residuals fell within the $95 \%$ confidence interval of the observed total volume outside bark, and most of the residuals were less than 1 SD away from the observed values
(Figure 5). Therefore, we found no significant geographic difference in total volume estimation within the State of Alaska, and all the statewide volume models were tested and found to be accurate for all the six DOF areas.

\section{Discussion and Conclusion}

Each of the eight Alaska statewide volume models was tested to be accurate for estimating the cubic-foot volume of white spruce in Alaska. The total stem and merchantable volume models developed in this study display excellent goodness of fit $\left(R^{2} \geq 0.994\right)$ and high levels of significance (Table 3 ). When tested on the validation sample set, both the total stem and merchantable volume models were accurate, and the prediction errors were not significantly different from 0 (Figure 3). The high coefficient of determination $\left(R^{2}\right)$ is a function of the growth pattern of white spruce trees and the sampling method.

White spruce is a medium-size tree that tapers quickly from a small root collar (stump) so that sections of the entire stem are close to the geometric shape of a paraboloid or cone (Husch et al. 1993). In addition, the sample trees were measured in $4-\mathrm{ft}$ lengths so that each section was close to a geometric shape, which lessened the natural variation. This produced a total stem model close to a function of $D^{2} H$, which describes the geometric shape of a cone, thus producing a high $R^{2}$. 


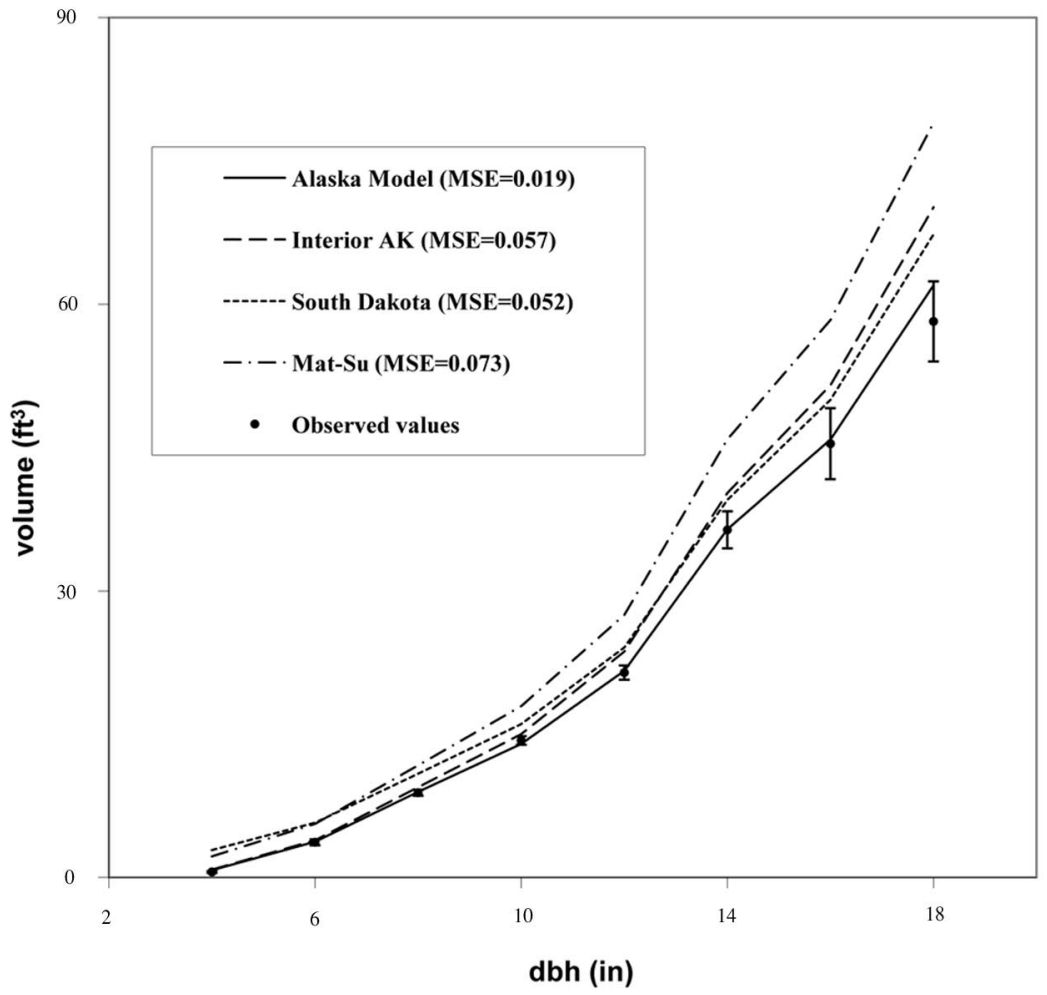

Figure 3. Mean predicted and observed (with $95 \%$ confidence interval) merchantable volume to a 4 -in. top inside bark of the 201 validation sample trees. Predictions were obtained with the Alaska model and three other white spruce volume models. Mean square error (MSE) of predicted values is presented for each model. Reference models include the Interior Alaska model (Haack 1963), the South Dakota model (Beagle 1979), and the Alaska Mat-Su model (Larson and Winterberger 1988).

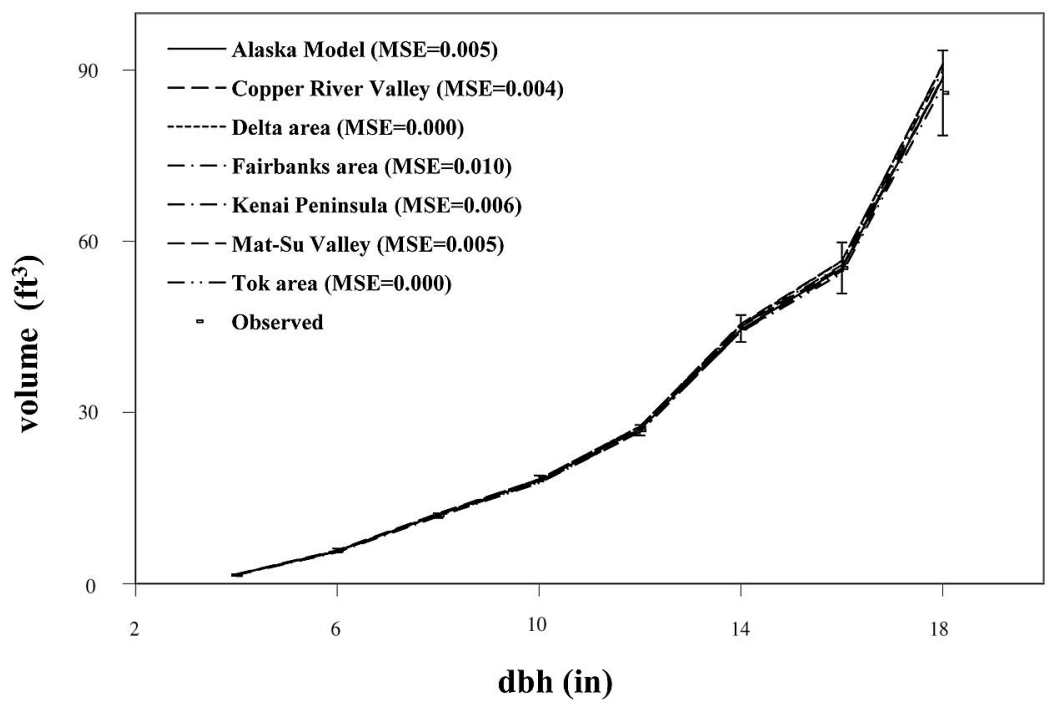

Figure 4. Mean predicted and observed total volume outside bark $\left(\mathrm{ft}^{3}\right)$ of the 201 validation sample trees, with $95 \%$ confidence interval (vertical bars) of the observations. Mean square error (MSE) of predicted values is presented for each model. Reference models are in the same form as the Alaska model but are calibrated only from sample data of each DOF area.

Compared with three existing volume models for white spruce, the Alaska merchantable model was of superior accuracy. The South Dakota (Beagle 1979) and the Mat-Su (Larson and Winterberger 1988) models overestimate merchantable volume of all tree sizes. The interior Alaska model developed by Haack (1963) was accurate for small diameter trees, but the error increased with increasing dbh (Figure 3). All models included in this study overestimate the volume of large diameter trees. There are few white spruce trees in northern Alaska that reach a dbh of 18 in. (Table 1; Malone and Liang 2009). In this study, the sample size of large trees is small, which accounts for a decrease in accurate volume estimates of large white spruce trees, although the Alaska model estimates are within the confidence interval.

Most existing tree volume models estimate volume from a $1-\mathrm{ft}$ high stump. Modern logging equipment, such as feller bunchers, cut stumps at 6 in. above the ground, which captures more volume at 

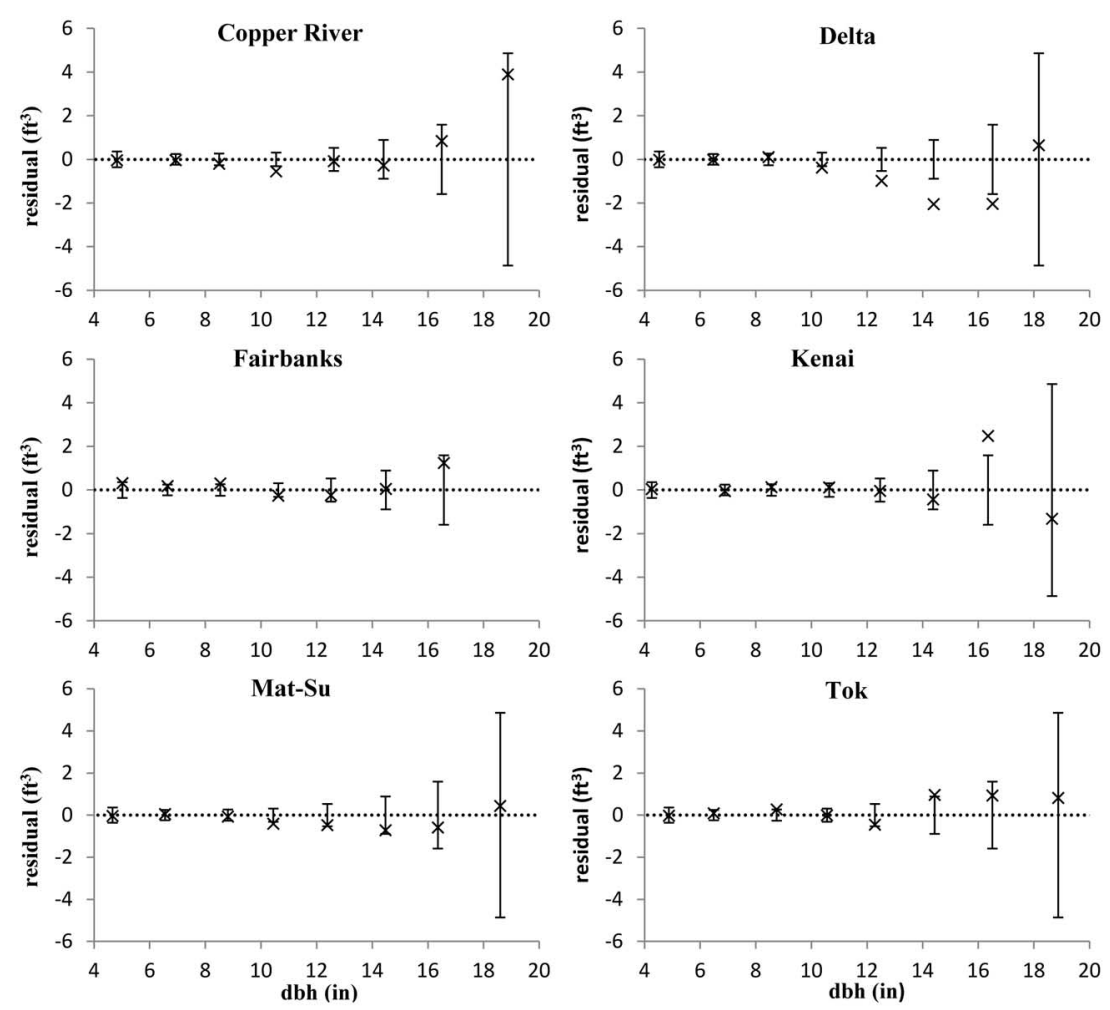

Figure 5. Test of model accuracy on validation samples by DOF areas. Residuals are the difference between predicted and observed total volume outside bark $\left(\mathrm{ft}^{3}\right)$. Vertical bars represent 1 SD of the observed values.

harvest. This difference in harvestable volume can be significant because about half of the volume of a white spruce tree is in the first $16-\mathrm{ft} \log$; in a random subsample of 50 trees used in this study, $54 \%$ of the volume was found in the first log. To reflect that increase in harvestable volume due to modern logging equipment, we estimated total and merchantable volume from a 6-in. stump.

It should be noted that to estimate merchantable volume inside or outside bark, total stem volume must be obtained first. If actual total stem volume data is available, merchantable volume model 2 is recommended because of its high goodness of fit. Otherwise, total stem volume predicted by model 1 should be used to replace the observed volume and in this case the two-stage merchantable volume model 3 should replace model 2 in estimating merchantable volume to avoid bias estimation.

A Kuskokwim River Valley white spruce model (Dippold and Farr 1971) estimates merchantable volume to a 4-in. top outside bark. Compared with the merchantable volume model developed in this study, the Kuskokwim River Valley model underestimates the merchantable volume of the validation sample. The difference between the two models may be largely due to different sampling procedures instead of geographic difference. The Kuskokwim data set contains only trees greater than 5 -in. dbh, and volume was calculated from a 1-ft stump instead of a 6-in. stump used for our statewide model. The trees from the Kuskokwim data set were measured in 8.15 - $\mathrm{ft}$ sections, and the Smalian formula was used to calculate volume. The Smalian formula estimates volume accurately for short logs such as the 4- $\mathrm{ft}$ sections used in our study. However, the Smalian formula is less accurate for estimating volume of logs longer than $4 \mathrm{ft}$ (Husch et al. 1993, Avery and Burkhart 2002).

This study provides cubic-foot volume estimates of standing white spruce trees for Alaska; many existing models present board- foot volume. Cubic-foot volume or a volume-weight measurement is more commonly used in the contemporary forest products industry, which is capable of utilizing the entire tree instead of only solid sawn lumber (Nilsson and Wernius 1976). A board-foot scale does not account for bark, sawdust, slabs, and small diameter wood. In addition, for trees sold on an international market, cubic-foot volume can be easily and accurately converted to metric scale by multiplying $\left(1 \mathrm{ft}^{3} \times 0.02832=1 \mathrm{~m}^{3}\right)$. Board-foot volume can be converted to cubic foot or metric scale but only on an individual stem basis, which is time-consuming.

The Alaska models were developed with data collected from 2,016 trees of various sizes and from 43 forest stands throughout interior and southcentral Alaska. These models provide a simple and accurate tool for researchers and resource managers to estimate white spruce total and merchantable cubic-foot volume, both inside or outside bark from a 6-in. stump.

Additional research should be directed to development of cubic foot/weight relationships because much of the North American and international forest products industry uses weight and conversion factors for solid wood cubic content in relationship to weight of wood and bark.

\section{Literature Cited}

AVERY, T.E., AND H.E. BuRKHART. 2002. Forest measurements, 5th ed. McGraw-Hill Inc., New York. 456 p.

BASKERVILLE, G.L. 1972. Use of logarithmic regression in the estimation of plant biomass. Can. J. For. Res. 2(1):49-53.

BEAGLE, L.D. 1979. Cubic-foot volume tables for white spruce in the Black Hills. USDA For. Serv., Res. Note RM-266, Rocky Mountain Forest and Range Experiment Station, Fort Collins, CO. 2 p.

Brackley, A.M., V. Barber, AND C. PinKel. 2010. Developing estimates of potential demand for renewable wood energy products in Alaska. USDA For. Serv., PNW-GTR-827, Pacific Northwest Research Station, Portland, OR. 38 p. 
BRUCE, D., AND T.A. MAX. 1989. Use of profile equations in tree volume estimation. P. 213-220 in State-of-the-art methodology of forest inventory: A symposium proceedings, LaBau, V.J., and T. Cunia (eds.). USDA For. Serv., PNW-GTR-263, Pacific Northwest Research Station, Portland, OR.

DipPOLD, R.M., AND W.A. FARR. 1971. Volume tables and equations for white spruce, balsam poplar, and paper birch of the Kuskokwim River Valley, Alaska. USDA For. Serv., Res. Note PNW-147, Pacific Northwest Research Station, Portland, OR. $8 \mathrm{p}$.

Gregory, R.A., AND P.M. HAaCK. 1964. Equations and tables for estimating cubic-foot volume of interior Alaska tree species. USDA For. Serv., Res. Note NOR-6, Northern Forest Experiment Station, Juneau, AK. 20 p.

HAACK, P.M. 1963. Volume tables for trees of interior Alaska. USDA For. Serv., Res. Note NOR-5, Northern Forest Experiment Station, Juneau, AK. 11 p.

Harlow, W.M., E.S. HarRaR, J.W. Hardin, AND F.M. White. 1996. Textbook of dendrology, 8th ed. McGraw-Hill Inc., New York. 534 p.

Huang, S., D. Price, and S.J. Titus. 2000. Development of ecoregion-based height-diameter models for white spruce in boreal forests. For. Ecol. Manage. 129:125-141.

Husch, B., C.I. Miller, AND T.W. BeERs. 1993. Forest mensuration, 3rd ed. Krieger Publishing Co., Malabar, FL. 402 p.

HuTCHISON, K. 1967. Alaska's forest resource. USDA For. Serv., Res. Bull. PNW-19, Pacific Northwest Research Station, Portland, OR. 74 p.

LARSON, F.R., AND K.C. WINTERBERGER. 1988. Tables and equations for estimating volumes of trees in the Susitna River Basin, Alaska. USDA For. Serv., Res. Note PNW-RN-478, Pacific Northwest Research Station, Portland, OR. 20 p.

LIANG, J. 2010. Dynamics and management of Alaska boreal forest: An all-aged multi-species matrix growth model. For. Ecol. Manage. 260:491-501.

LIANG, J. 2012. Mapping large-scale forest dynamics: A geospatial approach. Land Ecol. 27(8):1091-1108.

Liang, J., M. Zhou, D.L. Verbyla, L. Zhang, A.L. Springsteen, and T. Malone. 2011. Mapping forest dynamics under climate change: A matrix model. For. Ecol. Manage. 262:2250-2262.

MAISCH, J.C. 2009. Annual report 2009. Alaska Department of Natural Resources, Division of Forestry, Anchorage, AK. 68 p.

Malone, T., AND J. LiAnG. 2009. A bark thickness model for white spruce in Alaska northern forests. Intl. J. For. Res. 2009:Article ID 876965. 5 p.
Neter, J., M.H. Kutner, C.J. Nachtsheim, and W. Wasserman. 1996. Applied linear statistical models, 4th ed. WCB/McGraw-Hill, Boston, MA. 1,408 p.

Nienstaedt, H., AND J. Zasada. 1990. Pinaceae, pine family, white spruce. P. 389-442 in Silvics of North America: Volume 1. Conifers, Burns, R.M., and B.H. Honkala (tech. coords.). Agriculture Handbook 654, USDA For. Serv., Washington, DC.

NilsSon, P.O., AND S. WerniUs. 1976. Whole-tree utilization: A method of increasing the wood supply. Ecol. Bull. 21:131-136.

OetTeLT. 1765. Praktisher bewis, das deis mathesis bey dem forstwesen unentbehrliche dienste thue. Eisenach. [As cited in Bruce and Max 1989.]

Ruefenacht, B., M.V. Finco, M.D. Nelson, R. CZaplewski, E.H. Helmer, J.A. BlaCKARD, G.R. Holden, ET AL. 2008. Conterminous U.S. and Alaska forest type mapping using Forest Inventory and Analysis data. USDA Forest Inventory and Analysis Remote Sensing Applications Center. Available online at fsgeodata.fs. fed.us/rastergateway/forest_type; last accessed Feb. 21, 2012.

Ryan, B., B. Joiner, And J. Cryer. 2005. Minitab handbook, 5th ed. Brooks/ Cole-Thomson Learning, Belmont, CA. 505 p.

SCHREUder, H.T., T.G. GREGOIRE, AND G.B. WoOd. 1993. Sampling methods for multiresource forest inventory. John Wiley and Sons, New York. 446 p.

SMALIAN, L. 1837. Beitrag zur holmesskunst. Stralsund. 124 p. [As cited in Bruce and $\operatorname{Max} 1989$.

SOIL STAFF SURVEY. 1999. Soil taxonomy: A basic system of soil classification for making and interpreting soil surveys, 2nd ed. USDA NRCS Handbook 436. Natural Resources Conservation Service, Washington, DC. 871 p.

SpRUGEL, D.G. 1983. Correcting for bias in log-transformed allometric equations. Ecology 64(1):209-220.

STATE OF AlASKA. 2007. Alaska economic performance report 2007. Alaska Office of Economic Development, Anchorage, AK. 49 p.

VIERECK, L.A., AND E.L. LiTTLE. 2007. Alaska trees and shrubs. University of Alaska Press, Fairbanks, AK. 359 p.

WOODALL, C.W. 2010. Carbon flux of down woody materials in forests of the North Central United States. Intl. J. For. Res. 2010:Article ID 413703. 9 p.

WoOldRIGe, J.M. 2009. Introductory econometrics: A modern approach, 4th ed. South-Western Publishing Co., Cincinnati, OH. 849 p. 